\title{
Formación especializada en España: y después de la troncalidad, ¿qué?
}

\author{
Amando MARTíN-ZURRO
}

Hablar en España de troncalidad del sistema MIR significa remontarnos a la segunda mitad de la década de los años ochenta cuando, siendo Luis Hernando presidente del Consejo Nacional de Especialidades, y yo, su afortunado secretario, elaboramos un primer borrador de decreto de troncalidad que pasó rápidamente a llenarse de polvo en algún cajón ministerial sin llegar a ver la luz del día. Posteriormente hemos sido muchos los que, de vez en cuando, hemos osado hablar y escribir sobre el asunto sin ser escuchados o leídos. Ha sido a mediados de la primera década de este siglo cuando el asunto pasó a ser objeto de atención por los responsables ministeriales y del Consejo Nacional de Especialidades y alcanzó la meta de ser publicado en forma de decreto en el Boletín Oficial del Estado ¡en 2014!, tras muchos años de debates más o menos sesudos. Tras su publicación, el decreto fue objeto de múltiples críticas, más o menos justificadas, algunas con claros tintes corporativistas en la tan manida línea de defensa centrada en 'y de lo mío, qué.' Muchos, entre los que me cuento, dijimos a quien quiso escucharnos que el proyecto de troncalidad adolecía de una gran rigidez en su planteamiento conceptual y estructural, entre otras cosas por establecer un período y contenidos homogéneos de formación para el conjunto de las especialidades, con independencia de la naturaleza y necesidades de cada una, y dejando algunas fuera de esta dinámica. Si a esta rigidez evidente se le suman los ataques procedentes de diversas sociedades científicas y comisiones nacionales de especialidad, el resultado podía adivinarse sin dificultad: el proyecto de troncalidad estaba condenado al fracaso y, como en los años ochenta, a entrar a formar parte de esa bibliografía olvidada de iniciativas ministeriales fallidas.

Un lustro después de la fracasada troncalidad, el nuevo gobierno llegado en los últimos meses de 2018 planteó la elaboración de un decreto de especiali-

\section{Specialised training in Spain: \\ and after the core curriculum, what's next?}

Talking about the core curriculum of the MIR system in Spain means going back to the second half of the eighties when Luis Hernando, then president of the National Council of Specialties, and I, his fortunate secretary, drew up a first draft of the core curriculum decree that was to soon end up gathering dust in some drawer at the Ministry without ever seeing the light of day. Subsequently, from time to time, many of us have dared to speak and write about the matter without anyone reading or listening to us. It was in the middle of the first decade of this century when the issue came to the attention of ministerial officials and the National Council of Specialties and finally accomplished the goal of being published in the form of a decree in the Official State Gazette (in 2014!) after many years of more or less judicious debates. After its publication, the decree was the object of a great deal of, to some extent justified, criticism, some clearly tinged with corporatist interests that come out in the use of the much-hackneyed line of defence focused on 'and what about me?' Many of us, including myself, told those who wanted to listen that the conceptual and structural approach to the core curriculum project was too rigid, among other things because it established a set of contents and a training period that were the same for all the specialties, regardless of the nature and needs of each one, and some were even left out of this dynamic altogether. If, in addition to this evident rigidity, we add the attacks from various scientific societies and national specialty commissions, there are no prizes for guessing the result: the core curriculum project was doomed to fail and, as in the 1980s, to become part of that forgotten list of unsuccessful ministerial initiatives.

Five years after the failed attempt to implement the core curriculum, the new government, which came to power towards the end of 2018, proposed the drafting of a specialties decree which, apparently,
Vicepresidente de la Fundación Española de Educación Médica.

E-mail:

a.martinzurro@gmail.com

(c) $2019 \mathrm{FEM}$

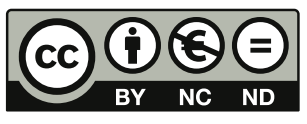

Artículo open access bajo la licencia CC BY-NC-ND (https:// creativecommons.org/licenses/ by-nc-nd/4.0/).

ISSN: 2014-9832

ISSN (ed. digital): 2014-9840 
dades en el que, al parecer, se contempla una estructuración más flexible de la formación manteniendo unas competencias transversales comunes que han de adquirir todos los especialistas. Se puede abrir una ventana a la esperanza en la medida en que los responsables actuales del ministerio y del Consejo Nacional de Especialidades hayan analizado con acierto los errores cometidos previamente y estén dispuestos a corregirlos. Como dicen los anglosajones, entramos en una etapa presidida por el lema 'wait and see'.

La troncalidad tiene sentido en la medida en que determina conjuntos de competencias que deberían compartir, poseer y ejercer profesionales de distintas especialidades, dotándoles de mayor potencialidad transversal, equilibrando una tendencia exagerada a la superespecialización y flexibilizando el mercado de trabajo. Las competencias de los especialistas sanitarios deben responder a tres categorías que han de guardar un exquisito equilibrio entre ellas para generar el mayor grado posible de efectividad y eficiencia de sus actuaciones: asociadas a la profesión, asociadas a la especialidad y asociadas al contexto.

Las primeras son las que pueden englobarse también bajo la denominación de 'transversales' en la medida en que son comunes a todas las ramas de la profesión, aunque con grados y contenidos distintos en razón de cada especialidad. Por poner un ejemplo exagerado, no pueden ser iguales las competencias transversales que ha de poseer un anatomopatólogo que un médico de familia. Muchas -por no decir todas- las competencias de este grupo deberían adquirirse durante la formación graduada, dejando para la fase de posgrado algunos aspectos que pueden asimilarse más fácil y coherentemente al tomar contacto directo con el ejercicio profesional propiamente dicho. Una integración mucho más estrecha que la actual entre las distintas fases del continuo formativo podría ayudar bastante en este ámbito.

Las competencias asociadas a la especialidad son aquellas que forman parte de su cuerpo doctrinal y práctico y, por tanto, hacen referencia directa al contenido del desempeño profesional autónomo. Las especialidades pueden clasificarse desde numerosas perspectivas (clínica, laboratorio, imagen, médica, quirúrgica, mixta, por grupos de edad y sexo, salud pública...), pero la taxonomía que puede englobar un mayor número de ellas podría basarse en tres grupos esenciales:

- Con acción directa sobre las personas y pacientes a nivel individual o colectivo, con independencia del tipo de problema o necesidad de salud contemplated a more flexible structure of training and the intention of maintaining common crosscutting skills that all specialists have to acquire. This can offer us some hope, as it would seem that the current heads of the Ministry and of the National Council for Specialities have performed a proper analysis of the mistakes made in the past and are prepared to correct them. We therefore enter what we could call the 'wait and see' stage.

The core curriculum makes sense insofar as it determines sets of competencies that should be shared, possessed and practised by professionals from different specialities, thereby endowing them with greater cross-cutting potential, balancing an exaggerated tendency towards super-specialisation and making the labour market more flexible. In order to ensure health specialists go about their practice with the highest possible degree of effectiveness and efficiency, their competencies must belong to three perfectly balanced categories: those associated with the profession, those associated with the specialty and those associated with the context.

The first are competencies that could also be called 'cross-cutting', since they are common to all the branches of the profession, although with different degrees and contents depending on each speciality. To give an exaggerated example, the cross-cutting skills that a pathologist must possess cannot be the same as those of a family doctor. Many - if not all of the competencies in this group should be acquired during graduate training, whereas certain aspects that can be assimilated more easily and coherently by coming into direct contact with professional practice itself should be left for the postgraduate phase. A much closer integration of the different phases of the training continuum than currently exists could be a valuable aid in this area.

The competencies associated with the specialty are those that form part of its body of doctrine and practice and, therefore, refer directly to the content of the autonomous performance of the profession. Specialties can be classified from numerous perspectives (clinical, laboratory, imaging, medical, surgical, mixed, age and gender, public health, etc.), but a taxonomy capable of encompassing a greater number of them could be based on three essential groups:

- Acting directly upon people and patients at an individual or collective level, regardless of the type of problem or health need they present and the deteriorated apparatus or system that causes it ('general' specialties).

- Acting directly upon people and patients, to deal with one or more deteriorated apparatuses or systems (classic medical-surgical specialties). 
que presenten y del aparato o sistema deteriorado que lo cause (especialidades 'generalistas').

- Con acción directa sobre personas y pacientes, para intervenir sobre uno o más aparatos o sistemas deteriorados (especialidades médico-quirúrgicas 'clásicas').

- Sin acción directa sobre personas o pacientes, y dedicadas al manejo e interpretación de técnicas diagnósticas (especialidades de servicios centrales, esencialmente laboratorios e imagen). Para este grupo debería valorarse la conveniencia de seguir una formación de grado idéntica a los de los otros dos grupos o si sería más adecuado diseñar currículos específicos en los que una parte de los contenidos actuales se combinara con otros procedentes de ciencias, como la físico-química, o ciertas ingenierías.

Las competencias asociadas al contexto han de conseguir la máxima adaptación del profesional a las características de este, sea el sistema sanitario en su conjunto, su organización y niveles, el tipo de hospital (de alta tecnología, comarcal...), el ámbito poblacional (urbano, rural...), las características demográficas, epidemiológicas, socioculturales y económicas, las disponibilidades tecnológicas y de otro tipo de recursos, etc. Cuanto mejor sea la adaptación competencial al contexto, más fácil será optimizar las actuaciones del profesional desde las perspectivas de efectividad y eficiencia.

En mi opinión, un diseño ideal de formación especializada debería contemplar en su construcción todos los elementos reseñados previamente $y$, tanto en el caso de las competencias transversales como en las de especialidad, potenciar la polivalencia y capacidad de adaptación del profesional a los distintos tipos de contexto señalados. Ese debería ser el objetivo formativo final, llámese troncalidad o de cualquier otra manera.

La respuesta al interrogante planteado en el título de este editorial tienen que efectuarla, desde la perspectiva legal y después en los programas formativos, los responsables ministeriales y del Consejo Nacional de Especialidades tras escuchar las opiniones de las instituciones, centros y expertos implicados. Los errores cometidos en el diseño de la troncalidad no deberían volverse a repetir, aunque ello no pueda descartarse totalmente, ni tampoco debe dejar de valorarse el riesgo de entrar en una nueva etapa de estancamiento y ausencia de toma de decisiones tan larga o más que la que ha precedido y seguido al decreto de troncalidad.
- With no direct action on people or patients, but instead dedicated to the management and interpretation of diagnostic techniques (central services specialties, essentially laboratories and imaging). It is necessary to consider whether it is better for this group to follow a degree course that is identical to those of the other two groups or whether it would be more appropriate to design specific curricula in which part of the current contents are merged with others from sciences, such as physico-chemistry, or certain engineering disciplines.

Competencies associated with the context must provide the professional with the means to adapt as far as possible to characteristics of that context, whether it is the health system as a whole, its organisation and levels, the type of hospital (high technology, regional, etc.), the population (urban, rural, etc.), demographic, epidemiological, sociocultural and economic characteristics, technological availability and other resources, and so forth. The better the adaptation of competencies to the context is, the easier it will be to optimise the actions carried out by the professional in terms of effectiveness and efficiency.

In my opinion, an ideal design for specialised training should include all the elements outlined above in its construction and, in the case of both cross-cutting and specialty skills, enhance the versatility and adaptability of the professional to the different types of context indicated. That should be the final aim of training, whether it is called the core curriculum or by any other name.

The answer to the question posed in the title of this editorial must be given, from a legal perspective and then in the training programmes, by the heads of the Ministries and of the National Council for Specialities after listening to the opinions of the institutions, centres and experts involved. The mistakes made when designing the core curriculum should not be repeated, although this cannot be completely ruled out. Likewise, we must not neglect the risk of entering a new stage of stagnation and absence of decision making that is as long or longer than the one that preceded and followed the core curriculum decree. 